\title{
Clustering of Health and Wellness Tourists Based on Tourism Motivation
}

\author{
Tao Ting ${ }^{1, \text { a }}$, Li Changyu ${ }^{2}$, Lu Changtai ${ }^{1, b^{*}}$, Cai Kexin ${ }^{1}$, Zheng Zhiping ${ }^{1}$, and He Linjun ${ }^{1}$ \\ ${ }^{1}$ School of Business and Tourism, Sichuan Agricultural University, Dujiangyan, 611830, China \\ ${ }^{2}$ Forestry and Grassland Bureau of Wenchuan County, Wenchuan, 623000, China
}

\begin{abstract}
In this paper, exploratory factor analysis, cluster analysis and other methods are used to study the health and wellness tourists based on tourism motivation, the results showed that: (1) the motivation of health and wellness tourism can be divided into three push motives: knowledge and experience, social and health, exploration and reflection; three pull motives: food and cultural activities, supporting facilities and information, natural and interpersonal environment. (2) According to the motivation, there are four types of tourists: seeking knowledge and health and wellness, facility service and environmental experience, exploration and reflection, and nearby travel. (3) There are significant differences among the four different types of health and wellness tourists in age, education level, occupation and monthly income.
\end{abstract}

\section{Introduction}

As a new way of travel and life style, health and wellness tourism has been developing rapidly in practice and has attracted the attention of academic circles. According to "National Health and Wellness Tourism Demonstration Base Standard" (LB/T 051-2016), Health and Wellness Tourism refers to the sum of all kinds of tourism activities that make people reach a good state of natural harmony in body, mind and spirit through various means such as nourishing the body, nourishing the diet, cultivating the mind and caring for the environment ${ }^{[1]}$. However, the research results of health and wellness tourism at home and abroad show great differences. Related studies are mostly carried out abroad with health and wellness tourism destinations as $\operatorname{cases}^{[2]}$. In the empirical quantification, the relationship among the variables such as health and wellness tourists' satisfaction, tourists' emotional response, overall destination image and behavioral intention was studied ${ }^{[3]}$. Current domestic research on health and wellness tourism is still in its infancy stage ${ }^{[4]}$, the research focuses on the development of health and wellness tourism industry and product development, as well as the distribution and evaluation of health and wellness tourism resources ${ }^{[5-7]}$. There is a large gap in theoretical framework and empirical research ${ }^{[8]}$.

Tourist clustering research is the theoretical basis and basis for market segmentation and marketing of tourist destinations $s^{[9]}$. Therefore, the study of tourist clustering has important theoretical significance and practical value for grasping the tourism market demand. Tourism motivation is one of the most commonly used classification methods in domestic and foreign tourist clustering research. Scholars at home and abroad have carried out cluster studies on urban residents ${ }^{[9]}$, religious tourism ${ }^{[10]}$ and black tourism ${ }^{[11]}$, divided different types of tourists, and accumulated abundant tourism research results, but few have involved cluster analysis on health and wellness tourism groups.

Based on this, this study focuses on the health and wellness tourism field. Starting from the perspective of tourism motivation, this study conducts a cluster study on health and wellness tourism tourists and discusses their type characteristics, so as to provide theoretical reference for a deeper understanding of the health and wellness tourism market demand and the promotion of the sustainable development of the health and wellness tourism industry.

\section{Research methods and data collection}

This paper mainly uses the questionnaire survey method for data collection. The preliminary questionnaire was designed according to the tourism motivation scale in the existing research, and the preliminary questionnaire was revised in combination with the research group's interview materials and expert suggestions on health and wellness tourists in the health and wellness leisure tourism resort of Tianfu Qingcheng in Dujiangyan to form the initial health and wellness tourism motivation scale ${ }^{[12]}$. A preliminary survey was conducted in Dujiangyan City from November 13, 2020 to November 20, 2020, and a total of 200 questionnaires were collected. According to the results, some questions were deleted and optimized to obtain the formal questionnaire, which consisted of three parts. The first part was about the push motivation of health and wellness tourism, with 11 measurement items. The second part is about the pull motivation of health and wellness tourism, 14 measurement items; the third part is

a Author: Tao Ting, (E-mail)1601647005@qq.com.

b* Corresponding author: Lu Changtai, (E-mail)lctwjy@163.com 
demographic characteristics, including gender, age, education level, occupation and average monthly income.

The formal survey was conducted in the health and wellness tourism resort and health and wellness tourism town of Kunming, Panzhihua and Xichang from November 25, 2020 to December 3, 2020. A total of 378 questionnaires were collected, 12 invalid ones were rejected, and 366 were effectively collected with an effective recovery rate of $96.8 \%$.

\section{Results and discussion}

\subsection{Testing of validity and reliability}

SPSS23.0 was used to analyze the reliability of the data. The reliability coefficient of the push motivation scale was 0.866 , and the reliability coefficient of the pull motivation scale was 0.876 , indicating that the reliability of the scale was good.

Principal component analysis and maximum variation method were used to conduct exploratory factor analysis of push motivation and pull motivation, respectively. The results showed that the $\mathrm{KMO}$ value of push motivation was 0.844 and the KMO value of pull motivation was 0.897 , which passed the Butler spherical significance test level, and was suitable for factor analysis. The results of factor rotation show that three factors of driving motivation can be extracted, which are named as knowledge and experience(KE), social and health(SH), exploration and reflection(ER), and three common factors of pull motivation can also be extracted. Naming them as natural and interpersonal environment (NIE), supporting facilities and information(SFI), food and cultural activities(FCA), the scale construction validity is good.

\subsection{Clustering analysis}

K-means analysis in SPSS23.0 clustering analysis is used for clustering. As shown in Table 1, tourists can be divided into 4 categories according to tourism motivation. The $F$ value of variance analysis and its significance indicate that there are significant differences among the 6 dimensions, and the clustering effect is good.

Table1. Results of cluster analysis of tourism motivation of health and wellness tourists

\begin{tabular}{|c|c|c|c|c|c|c|}
\hline $\begin{array}{c}\text { Motivation } \\
\text { dimension }\end{array}$ & Class 1 & Class 2 & Class 3 & Class 4 & F value & P value \\
\hline KE & 0.5870 & -0.8732 & -0.3334 & -3.1578 & 138.893 & 0.000 \\
\hline SH & 0.6350 & -0.1980 & -0.8259 & -3.1568 & 184.903 & 0.000 \\
\hline ER & 0.5188 & -1.3813 & 0.0036 & -1.7782 & 136.498 & 0.000 \\
\hline FCA & 0.4990 & -0.5382 & -0.4489 & -2.0377 & 56.229 & 0.000 \\
\hline SFI & 0.3950 & 0.6006 & -0.8837 & -2.9258 & 137.573 & 0.000 \\
\hline NIE & 0.4858 & 0.4417 & -0.8813 & -4.0108 & 267.471 & 0.000 \\
\hline
\end{tabular}

According to the results of cluster analysis, health and wellness tourists are divided into four types. (1) Class1: This group most identifies with the two motivations of "social and health" and "knowledge and experience", indicating that this group pays most attention to the acquisition of knowledge and the management of physical and mental health. Therefore, it is named as "knowledge seeking and health and wellness keeping type". (2) Class2: This group agrees with the motivation of "supporting facilities and information", followed by "natural and interpersonal environment". They are very concerned about the perfection of supporting facilities, the service of information consultation and the comfort of the environment in the health and wellness tourism destination, so they are named as "facility service and environmental experience type". (3) Class3: This group agrees with the motivation of "exploration and reflection", but disagrees with all other motives. Its motivation is concentrated, and it likes challenges, thinking and evaluation, so it is named as "exploration and reflection type". (4) Class4: This group has a low identification of each motive, and participates in health and welllness tourism or travels because the destination is close to home, so it is named as "nearby travel type".

\subsection{Chi-square analysis}

To understand tourists for four types of population characteristics, according to the clustering analysis results on the statistical analysis, and chi-square test, the results showed that in addition to gender, all kinds of tourists in age, culture level, occupation and average monthly income were with significant difference, specific analysis is as follows $\left({ }^{* * *}\right.$ significance level is less than 0.001$)$.

The gender difference of the four types of tourists is not significant, as shown in Table 2. In addition to "nearby travel type" mostly male, the other three types are mainly female.

Table2. Clustering Table-gender

\begin{tabular}{|c|c|c|c|c|c|}
\hline $\begin{array}{c}\text { Catego } \\
\text { ry }\end{array}$ & Project & Class 1 & Class 2 & Class 3 & Class 4 \\
\hline \multirow{2}{*}{ Gender } & Male & $38.2 \%$ & $31.7 \%$ & $36.2 \%$ & $71.4 \%$ \\
\cline { 2 - 6 } & Female & $61.8 \%$ & $68.3 \%$ & $63.8 \%$ & $28.6 \%$ \\
\hline
\end{tabular}

The age difference of the four types of tourists is very significant, as shown in Table 3. "Knowledge seeking and 
health and wellness keeping type" involves all ages, in line with the deepening of China's aging population, the awareness of greater health and the pursuit of a higher quality of life so that its health and wellness demand increased phenomenon. The age of "facility service and environmental experience type" is 36 years old or above, and more than half of the people are over 65 years old, which indicates that due to physical reasons, the elderly people pay more attention to the supporting facilities, public services and health and wellness tourism environment in the health and wellness tourism destination. "exploration and reflection type" tend to fall between the ages of 21 and 50. They are full of energy and are under a lot of pressure. They seek challenges to reduce stress and enjoy self-reflection in a relatively calm and leisurely environment. Although it also involves all ages, compared with young adults, young people, middle-aged and old people and other people have less pressure, and their lifestyle is not clear or has been adjusted and formed, their need for exploration and reflection is weak. "Nearby travel type" are all aged between 21 and 35 years old, they take advantage of work or study, the principle of nearby travel nearby.

Table3. Clustering Table-Age

\begin{tabular}{|c|c|c|c|c|c|}
\hline $\begin{array}{c}\text { Categ } \\
\text { ory }\end{array}$ & Project & Class 1 & Class 2 & Class 3 & Class4 \\
\hline \multirow{7}{*}{ Age $^{* * *}$} & $\begin{array}{c}\text { Age } 20 \\
\text { and below }\end{array}$ & $1.0 \%$ & $0.0 \%$ & $4.8 \%$ & $0.0 \%$ \\
\cline { 2 - 6 } & $21 \sim 35$ & $16.2 \%$ & $0.0 \%$ & $40.0 \%$ & $100.0 \%$ \\
\cline { 2 - 6 } & $36 \sim 50$ & $10.5 \%$ & $4.8 \%$ & $28.6 \%$ & $0.0 \%$ \\
\cline { 2 - 6 } & $\begin{array}{c}51 \sim 65 \\
\text { More than } \\
65 \text { years } \\
\text { old }\end{array}$ & $27.2 \%$ & $31.7 \%$ & $12.4 \%$ & $0.0 \%$ \\
\hline
\end{tabular}

The four types of tourists have significant differences in educational level, as shown in Table 4. "Knowledge seeking and health and wellness keeping type" and "exploration and reflection type" both involve different educational levels. The former is mainly junior college or undergraduate, while the latter is higher than the former except junior high school or below. Such tourists have higher educational level, and their demand for knowledge, health and reflection is greater. The educational level of "facility service and environment experience type" and "nearby travel type" is unevenly distributed. The former is mainly junior high school or below, and focuses on the experience brought by hardware facilities and information services as well as natural environment. And the latter is given priority to with the diploma of master's graduate student above, this kind of crowd is in reading or career period, take advantage of leisure play to relax, accord with its place stage.

Table4. Clustering Table-Educational Level

\begin{tabular}{|c|c|c|c|c|c|}
\hline Category & Project & $\begin{array}{c}\text { Class } \\
\mathbf{1}\end{array}$ & $\begin{array}{c}\text { Class } \\
\mathbf{2}\end{array}$ & $\begin{array}{c}\text { Class } \\
\mathbf{3}\end{array}$ & $\begin{array}{c}\text { Class } \\
\mathbf{4}\end{array}$ \\
\hline $\begin{array}{c}\text { Educatio } \\
\text { nal level }\end{array}$ & $\begin{array}{c}\text { Junior high } \\
\text { school and } \\
\text { below }\end{array}$ & $22.5 \%$ & $39.7 \%$ & $12.4 \%$ & $0.0 \%$ \\
\cline { 2 - 6 } & $\begin{array}{c}\text { Senior high } \\
\text { school or }\end{array}$ & $26.2 \%$ & $34.9 \%$ & $30.5 \%$ & $0.0 \%$ \\
\hline
\end{tabular}

\begin{tabular}{|c|c|c|c|c|c|}
\hline & $\begin{array}{c}\text { technical } \\
\text { secondary } \\
\text { school }\end{array}$ & & & & \\
\cline { 2 - 6 } & $\begin{array}{c}\text { Junior college } \\
\text { or } \\
\text { undergraduate }\end{array}$ & $48.7 \%$ & $25.4 \%$ & $52.4 \%$ & $28.6 \%$ \\
\cline { 2 - 6 } & $\begin{array}{c}\text { Master degree } \\
\text { or above }\end{array}$ & $2.6 \%$ & $0.0 \%$ & $4.8 \%$ & $71.4 \%$ \\
\hline
\end{tabular}

The differences in occupation of the four types of tourists are very significant, as shown in Table 5 . "Knowledge seeking and health and wellness keeping type" and "facilities service and environment experience type" are mainly retired people, who have no need of work and have enough time to travel. The "exploratory and reflective type" occupations are the most evenly distributed among the four categories, which are mainly employees of enterprises or individual businesses and "other" occupations, while the "nearby travel type" occupations are all "other" occupations, possibly because these occupations are relatively free in time.

Table5. Clustering Table-Occupation

\begin{tabular}{|c|c|c|c|c|c|}
\hline Category & Project & $\begin{array}{c}\text { Class } \\
1\end{array}$ & $\begin{array}{c}\text { Class } \\
2\end{array}$ & $\begin{array}{c}\text { Class } \\
\mathbf{3}\end{array}$ & $\begin{array}{c}\text { Class } \\
4\end{array}$ \\
\hline \multirow{5}{*}{ Occupation } & $\begin{array}{l}\text { Government } \\
\text { agency or } \\
\text { public } \\
\text { institution }\end{array}$ & $3.1 \%$ & $0.0 \%$ & $12.4 \%$ & $0.0 \%$ \\
\hline & $\begin{array}{l}\text { Enterprise } \\
\text { staff or } \\
\text { individual } \\
\text { business } \\
\end{array}$ & $14.1 \%$ & $11.1 \%$ & $29.5 \%$ & $0.0 \%$ \\
\hline & Student & $2.6 \%$ & $0.0 \%$ & $7.6 \%$ & $0.0 \%$ \\
\hline & $\begin{array}{c}\text { The } \\
\text { emeritus } \\
\text { and retired }\end{array}$ & $66.0 \%$ & $79.4 \%$ & $21.9 \%$ & $0.0 \%$ \\
\hline & others & $14.1 \%$ & $9.5 \%$ & $28.6 \%$ & $\begin{array}{c}100.0 \\
\%\end{array}$ \\
\hline
\end{tabular}

The average monthly income of the above four types of tourists is also significantly different, as shown in Table 6. "Knowledge seeking and health and wellness keeping type" is given priority to with 3001 RMB and above, "facilities service and environment experience type" with $6000 \mathrm{RMB}$ and the following is given priority to, income is the important factors influencing the health and wellness tourist motivation, the higher the income of the greater the demand of personal mental level, and "nearby travel type " is given priority to with high income people, but the main factors which influence the visit is near the tourist destination, convenient.

Table6. Clustering Table-Average Monthly Income

\begin{tabular}{|c|c|c|c|c|c|}
\hline Category & Project & $\begin{array}{c}\text { Class } \\
1\end{array}$ & $\begin{array}{c}\text { Class } \\
2\end{array}$ & $\begin{array}{c}\text { Class } \\
3\end{array}$ & $\begin{array}{c}\text { Class } \\
4\end{array}$ \\
\hline \multirow{4}{*}{$\begin{array}{l}\text { Average } \\
\text { monthly } \\
\text { income }^{*} \\
{ }^{*}\end{array}$} & $\begin{array}{l}\text { 3,000 RMB } \\
\text { and below }\end{array}$ & $19.4 \%$ & $23.8 \%$ & $28.6 \%$ & $0.0 \%$ \\
\hline & $\begin{array}{c}3,001 \sim 6,000 \\
\text { RMB }\end{array}$ & $54.5 \%$ & $66.7 \%$ & $46.7 \%$ & $14.3 \%$ \\
\hline & $\begin{array}{c}6,001 \sim 10,000 \\
\text { RMB }\end{array}$ & $20.4 \%$ & $9.5 \%$ & $23.8 \%$ & $28.6 \%$ \\
\hline & $\begin{array}{c}\text { More than } \\
10,000 \mathrm{RMB}\end{array}$ & $5.8 \%$ & $0.0 \%$ & $1.0 \%$ & $57.1 \%$ \\
\hline
\end{tabular}




\section{Conclusions}

Based on the above analysis, the research conclusions of this paper are as follows: (1) The tourism motivation of health and wellness tourists is divided into three push motives: knowledge and experience, social and health, exploration and reflection; three pull motives: food and cultural activities, supporting facilities and information, natural and interpersonal environment. (2) Health and wellness tourists can be divided into four types: knowledge seeking and health and wellness type, facilities service and environment experience type, exploration and reflection type, and nearby travel type. There was no significant difference in sex among the four types. There were significant differences in age, education level, occupation and monthly average income.

This study enriches the results of tourist clustering research. Health and wellness tourists are significantly different from other types of tourism groups in terms of type division. Health and and wellness tourists pay more attention to health and wellness cultural activities, environment and related supporting facilities or ideological health and other content. This also means that in the construction of health and wellness tourism resort, more attention should be paid to the design of health and wellness facilities and activities. At the same time, health and wellness tourism also includes sunshine health and wellness, forest health and wellness, spring health and wellness and other contents. Due to the research time and regional limitations, further empirical research is needed to determine whether the conclusions of this study are applicable to different health and wellness tourists.

\section{Acknowledgments}

This paper is one of the research results of "Research on Health Tourism Mode of Giant Panda National Park" (GJGY2019-ZC019), which is supported by National Park Research Center of Sichuan Social Science Key Research Base, and "Research on Optimal Path of Forest Health Products in Sichuan Province Based on 'Two Mountains' Theory" (201910626062), which is supported by Sichuan University Students' Innovation Training Program.

\section{References}

1. Department of Comprehensive Coordination, National Tourism Administration, School of Tourism, Sun Yat-sen University.LB/T 051-2016. National Health Tourism Demonstration Base [S]. National Tourism Administration,2016.01.05.

2. João R, Kazuo M, Peter N. Integrative diversification of wellness tourism services in rural areas-an operational framework model applied to east Hokkaido (Japan)[J]. Asia Pacific Journal of Tourism Research, 2018, 23(07):734-746.

3. Sharma P, Nayak J K. Testing the role of tourists' emotional experiences in predicting destination image, satisfaction, and behavioral intentions: A case of wellness tourism[J]. Tourism Management Perspectives, 2018,28: 41-52.

4. Zhou G M, Song R, Liu Q Q. Kang raise tourism research at home and abroad are reviewed and prospects $[\mathrm{J} / \mathrm{OL}]$. Resource development and the market: 1-19 [2020-12-23]. http://kns.cnki.net/kcms/detail/51.1448.n.20201030. 1309.016.html.

5. Yang X C, Song L Z, Zhong Y Y, et al. Spatial distribution characteristics and influencing factors of health tourism resources in Fujian Province [J]. Journal of Fujian Normal University (Natural Science Edition), 2019, 35(05):106-116.

6. Li J R, Xu D. Study on the construction of evaluation index system of forest health and tourism [J]. Forestry Economics, 2018,40(03):28-34.

7. Zhang $\mathrm{H}$ Q, Zhai X J, He D. Research on the innovation and development of forest health care industry based on industrial integration: A case study of Heilongjiang Province [J]. Forestry Economics, 2019, 41(08):51-61.

8. Li P, Zhao Y M, Ye H Y. Analysis of the concept of health tourism and international research progress [J].Tourism Forum,2020,13(01):69-81.

9. Chen D G, Miao C H. Research on Tourist Clustering Based on Tourism Motivation: A Case Study of Domestic Tourism of Kaifeng City [J]. Tourism Tribune, 2006, 21(06):22-28.

10. Luo J N, Zhao Y F. Research on China's religious cultural tourism market segmentation based on tourism motivation $[\mathrm{J}]$. Chinese Journal of Management,2015,12(08):1118-1123.

11. Wang J W, Zhang S Y. Black tourists in disaster sites: motivation, types and differences: A case study of Beicchuan earthquake site [J]. Geographical Research, 2016, 35(08):1576-1588.

12. Ashton A S. Spiritual retreat tourism development in the Asia Pacific region: investigating the impact of tourist satisfaction and intention to revisit: a Chiang Mai, Thailand case study[J]. Asia Pacific Journal of Tourism Research, 2018, 23(11):1098-1114. 